\title{
From disaster relief to disaster risk reduction: a consideration of the evolving international relief mechanism
}

\author{
D VAN NIEKERK*
}

\begin{abstract}
Disaster risk reduction is an ever-growing concept and finds its application within various disciplines. This article investigates the development of disaster risk reduction and some of the most important aspects which shaped it. The early years of international disaster relief are discussed and it is shown how a change in this system was necessitated by a variety of factors and international disasters, which exposed its weakness. The article argues that disaster relief and development aid were inextricably linked and it is this linkage which provided a catalyst for questioning the manner in which relief, and development assistance, were provided. The later emphasis on disaster preparedness and management is discussed, and international policies and mechanisms, which contributed to a gradual shift in focus towards disaster risk reduction, enjoy attention. The article concludes that solutions to disaster risks lie within a rigorous transdisciplinary focus.
\end{abstract}

Keywords: Disaster risk reduction, disaster relief, disaster preparedness.

Disciplines: Disaster management, history, public management.

\section{Introduction}

The development and progression in humankind's understanding of the world and life, ensured a continuous evolution in the response to events threatening our livelihoods. Humankind developed techniques to deal with natural hazards, either by aiming to contain the forces of nature, or by altering human own behaviour. The development of humankind brought with it an increase in the susceptibility towards hazardous exploitation (Williams, 2005; UNDP, 2004). It was only in the modern age that humankind aimed to study and understand what was called "natural disasters". This study increased our understanding of the causal factors and how humans contribute to their own demise though unsustainable development techniques.

* Dr Dewald van Niekerk is Director of the African Centre for Disaster Studies at North-West University's Potchefstroom campus.

Email: Dewald.vanNiekerk@nwu.ac.za. 
During the last century, several powerful natural disasters occurred in different parts of the world, in countries both technologically advanced and developing. The types of natural hazards that triggered these disasters varied from the unpredictable occurrence of earthquakes, to more predictable seasonal floods and periodic storms. Other less immediate and slowly evolving hazards such as drought and environmental degradation affected even more people with potentially greater costs for their future. More than anything else, the media images of natural disasters at the close of the twentieth century underscored and focussed upon the human consequences and social dimensions of these events (UNISDR, 2002).

This article aims to provide the reader with a brief investigation of the contribution of disaster relief, as well as the early concept of disaster preparedness, to the development of the concept of disaster risk reduction. It should be noted that the development of disaster risk reduction cannot only be discussed in terms of a timeframe or chronology of events. Some significant themes like the disaster relief agenda, development aid and assistance, disaster preparedness and response will be used to indicate the development of this multi-, and trans-disciplinary focus.

\section{Disaster relief}

A variety of different and varied occurrences had a significant impact on the development of disaster risk reduction. Aspects discussed below do not necessarily indicate a natural progression towards disaster risk reduction, but it should rather be seen as elements which ensured a realisation of the need for disaster risk reduction measures. It should, therefore, be stated clearly that the author does not believe that the contemporary attention which disaster risk reduction enjoys is a natural evolutionary process of just one discipline, nor can it be accurately linked to a chronological timeframe. It is rather the culmination of the activities and work of many different professionals and disciplines (see Jeggle in Rosenthal, Comfort \& Boin, 2001; UNISDR, 2003; Alexander, 1993; Wisner et al, 2004; Pelling, 2003).

Issues of disaster risk always enjoy heightened attention after a disaster. It is only logical to argue that some of the major disasters to strike the globe in the post-World War II era ensured a continuous focus on disaster and disaster relief related issues stimulated by modern news media, albeit only for a limited period subsequent to a disaster. The following section will therefore aim to address the contribution of disaster relief and development aid to the evolution of disaster risk reduction.

\section{Disaster relief and development aid}

A discussion on the international disaster relief mechanism would be inadequate if separated from development aid. It should, however, 
be noted that these two concepts must not be viewed as synonyms, although in many instances the division between development aid and disaster relief is blurred.

In this conceptualisation, disasters were events to be waited for and only after the disaster struck, would remedial action be taken to ensure a speedy return to normality (Moore, 1956). Many Less Developed Countries (LDCs), living with the legacy of the post-World War II, post-colonial era and then the post-Cold War, were mostly defenceless in the face of disasters and in dire need of economic development. This is quite evident in the Chinese famine of the early 1960s (Watkins, 2003) as well as the North Peruvian earthquake of 1970 (Forces of Nature, 2004). In most instances, communities were perceived to be helpless and required [international] intervention and assistance (Comfort et al., 1999; Pelling, 2003). This fatalistic attitude towards disasters lead to the stereotypical provision of relief after a disaster has occurred (Lechat, 1990; Alexander, 1993). The East Pakistan/Bangladesh cyclone, and resulting storm surge which killed approximately 300000 people in 1970 is a clear example of how the international community intervened to assist seemingly "helpless" populations (see Cuny, 1983), and in doing so, demonstrated strikingly incompetent management capacities (Ritchie, 1976). The Guatemalan earthquake of 1976 exhibited the same aid provision characteristics, to the extent that the affected population began to believe that they were helpless and in need of external intervention.

Jeggle points out:

(T)he conception of emergency assistance [disaster relief] has been predominantly one of providing immediate and short-term basic necessities of food, water, shelter and medical care to survivors of a specific catastrophe (in Rosenthal, Comfort \& Boin, 2001).

The provision of relief was therefore not linked to any form of long term development planning.

\section{The early years of international relief}

The earliest documented codes in dealing with early warning and relief were the Madras Famine Code of 1883, which was the forerunner to the Bengal Famine Code. The former aimed "to monitor grain prices as an indicator of famine". The latter (developed in 1895 and revised in 1913) spelled out in great detail the responsibilities of governments in the anticipation, response and recovery to droughts and floods, and the consequent loss of agricultural production (ISDR, 2004b). Until the 1920s, disaster relief was delivered strictly on a bilateral basis (from one nation to another). With the inception of the International League of the Red Cross and later Red Crescent Societies, international organisations started to play a more coordinating and intermediary role in disaster relief (Burton, Kates \& White, 1993; Gunn, 1992). Most of the humanitarian relief 
activities, both governmentally driven and private (Green, 1977), were born out of the World War II (e.g. British War Relief in the United States and Oxfam in Britain) (Black, 1992; Burton, Kates \& White, 1993). The devastation of the World War II on Europe firmly established the need for some form of mechanism to provide relief to people in their hour of need. Towards the end of the World War II (1943), the United Nations Relief and Rehabilitation Administration (UNRRA) became the first disaster enterprise instituted on a global scale (Gunn, 1992). It was also in this post-war period that different governments moved into a larger relief role than before, which was predominantly the domain of relief organisations. This is quite evident in the establishment of international aid agencies by the majority of the more developed countries (MDCs).

Examples are the establishment of the United States Agency for International Development (USAID) and the Office of Foreign Disaster Assistance, created by John F. Kennedy in 1961 (USAID, 2004). Other MDCs followed the example set by the USA and in 1969 the Canadian government established the Canadian International Development Agency (CIDA) (CIDA, 2008), Germany created the Deutsche Gesellschaft für Technische Zusammenarbeit (GTZ) GmbH in 1975 (GTZ, 2008) and the United Kingdom established the Ministry of Overseas Development in 1964 (to become the Department for International Development in 1997) with a Refugee and Relief Division (DFID, 2004).

These international development organisations had, in most cases, a two-fold objective: firstly, to implement the foreign policy of the mother country in the developing world; and secondly, to alleviate the plight of the poor. These objectives as well as the prevailing international political situation dictated the way in which aid and development assistance were given to countries in need. These international development agencies gradually started to form an important part of the international relief system.

\section{The international relief system}

Green (1977) states that the international disaster relief system since the 1970s consisted of four major elements: the United Nations, private organisations (e.g. Red Cross and others), donor governments (through their development agencies) and the international media. Cuny (1983) identifies five tiers within this relief system, that of primary donors, organisations receiving relief, international relief and development organisations, local government and non-governmental organisations (NGOs), and projects. An amalgamation of the focus of Green and Cuny will be used to discuss this international relief system.

\section{The United Nations and its agencies}

The UN, realising the importance of disaster relief, prioritised the international coordination of emergency assistance, and in 1971 
established the United National Disaster Relief Office (UNDRO) (UN, 1971; Burton, Kates \& White, 1993). UNDRO was to be the focal point in the UN system for disaster relief matters. UNDRO was initially created with a mandate to respond to natural disasters, but quickly expanded to include so called "man-made" disasters as well (UN Chronicle, 1985).

In its first few years of operation UNDRO never obtained the status proclaimed by Resolution $2816^{1}$ of the United Nations. Internal communication and lines of authority within and between UN agencies hampered the work of UNDRO. UNDRO, that mostly had to work though UN field staff, found this virtually impossible due to a lack of inter-agency cooperation and collaboration and the competition over relief fund raising within the UN system. Throughout its 20 years of existence UNDRO was beset by problems including an uncertain mandate, inadequate (and sometimes incompetent) staffing and funding, lack of in-country capacity, lack of support from other UN agencies (and on occasion the Secretariat), a long running dispute over whether or not it should be operational (i.e. physically involved in the handling and distribution of assistance), and poor credibility within the donor community (ODI, 1993). Its performance was regularly criticised in reviews by the UN and external parties. Perhaps the most fundamental of all of UNDRO's problems was that it was always the poor relation to the other, larger UN agencies that were directly involved in the relief operations.

The aftermath of the drought and famine in the Sahel and particularly Ethiopia in 1974 ensured a heightened focus on disaster relief. It is also in this era that UNDRO staff was expanded and it developed a solid base for its operations. Green (1977) says that the initial funding of UNDRO was on a bilateral basis (notably from the United States) but later became part of the UN budget. In most cases UNDRO worked through the resident staff of the United Nations Development Programme (UNDP) (Cuny, 1983). UNDRO did not itself control a major share of the resources being channelled to the affected population, or indeed have a substantial field presence during the response. It is questionable that it could ever have been expected to play an effective coordination role (ODI, 1993). In April 1992, UNDRO was absorbed within the newly created Department of Humanitarian Affairs (OCHA, 2008).

Currently the UN still provides for disaster relief through its many agencies (e.g. Office for the Coordination of Humanitarian Affairs (OCHA), UNICEF, World Food Programme (WFP), United Nations Children's Fund (UNICEF) and Food and Agricultural Organisation (FAO)). The UN specialised agencies can provide a wide variety of resources ranging from technical assistance to food. Many of these agencies have their own in-country staff that is capable of managing relief programmes.

1 UN Resolution 2816 establishment of an adequate permanent office in the United Nations to be the focal point in the UN system for disaster relief matters (called UNDRO). 


\section{Primary donors and international development agencies}

Cuny (1983) is of the opinion that the primary donors (e.g. private contributors, taxpayers, corporate donors and special interest groups) form the first tier in the international relief system. These donors normally do not have direct contact with the community for which the aid is intended and therefore donors tend to work through an implementing agency such as international relief or development organisations. Although, international development agencies are primarily responsible for implementing their respective country's foreign policies through development aid, they inevitably become involved in the provision of disaster relief.

Response by these international development agencies after a disaster has occurred, also started to influence the development agenda and the provision of development assistance. In many instances much needed development funds were redirected towards reconstruction and rehabilitation after a disaster. This is quite evident in the Andhra, Pradesh cyclone of 1977. Massive development funds were rerouted to Indian communities in need of immediate disaster assistance, with some significant long-term development consequences for the communities for which the development funds were intended (Cuny, 1983).

Smith (2002) emphasises the enormous impact of disasters on the development by indicating that in the year 1992 alone the world lost more money due to the impact of natural disasters estimated at US\$62 billion), than it spent on developmental (estimated at US\$60 billion). According to Munich Re (2007) in 2007 the global economic losses due to disasters were US\$75 billion, but much less than the US $\$ 220$ billion recorded in 2005. In the same year (2005) the official development assistance globally were US\$107 billion, and in 2006 showed a reduction to US\$105 billion (World Bank, 2008). In staying with the development agencies, Todaro (1994) argues that the impetus behind providing foreign aid was either politically or economically motivated. Today it is widely recognised that the Marshall Plan, was a means by the United States of America (USA) to contain the spread of communism through Europe. After the successful reconstruction of Europe, many of these established organisations continued their work of providing aid and relief to communities in want. Most of the relief organisations found themselves working exclusively in the LDCs (Black, 1992), with most of the foreign development assistance also going to these countries (Todaro, 1994). Once the balance of Cold War interests shifted from Europe to the developing world in the 1960 s, the containment policy of the USA development programme dictated a shift towards political, economic, and military support for geographically strategic "friendly" LDCs. Most of the aid programmes to the developing nations (not only those coming from the USA, but also Great Britain and France) were more aimed towards purchasing their security and propping up their sometimes shaky regimes, than promoting long-term social and economic development. At the other side of the Cold War spectrum, the socialist aid of the former Soviet Union was essentially also politically and strategically motivated, 
although its form and content differed somewhat (Todaro, 1994). These aid giving governments sometimes found themselves in an absolute conundrum - funding military might on the one hand while providing relief to those affected by these weapons.

\section{Private relief organisations}

In the early years of disaster relief (1950 onward), private agencies (widely known as non-governmental organisations - NGOs), generally provided a small portion of the assistance during a given disaster (Cuny, 1983). They however, became an important part of the relief mechanism, as they tended to be the first responders (Cuny, 1983). In most instances they already had in-country resources and were not extensively belaboured by bureaucratic channels. Private relief and development organisations also found themselves (most of the time) in political neutral terrain and could better provide aid in areas that were politically sensitive. This was quite evident in the Biafra war in the late 1960s; the Southeast Asian refugee crisis of the 1970s, the civil strive in Burundi in 1972, and Afghanistan in the 1980s. These private organisations also had the ability to provide different types of relief that were not easily matched by the official organisations (Green, 1977). Many more private organisations have been created since the 1960s and in many instances have developed thriving fundraising mechanisms.

One of the most cumbersome aspects associated with a multitude of private organisations is that their actions often tend to be uncoordinated, are frequently in competition, and also exhibit an alarming lack of collaboration (Ritchie, 2004). This lead to a duplication and waste of resources. Such was the case in the Ethiopian famine of the 1970s (which only became globally known through a television documentary made by Stephen Green working for a UN agency) and again in the early 1980s. In realising the scarcity of resources and the need for a coordinated approach, the Christian Relief and Development Association (CRDA) was established in Ethiopia in May 1973 (initially consisting of 13 members). It currently consists of over 200 NGOs, and faith based organisations (CRDA, 2004).

Jeggle (2005) indicates that another watershed in the international relief system and involvement of private organisations in providing disaster relief was the Bangladesh emergency after its independence war. More than 120 NGOs flocked to Bangladesh in order to provide relief aid. Although the UN was essentially managing the logistics of the fledgling country, many NGOs worked in a myriad of aspects, sometimes uncoordinated. The sometime uncoordinated interventions by NGOs and the varied standards applied when providing disaster relief provided the impetus to the development of two important documents. Firstly the "Code of Conduct for the International Red Cross and Red Crescent Movement and nonGovernmental Organisations in Disaster relief" was developed in 1994 by the International Red Cross and Red Crescent Movement. 
Secondly, the Sphere Project: Humanitarian Charter and Minimum Standards in Disaster Response by leading international humanitarian NGOs was introduced in 1997 (Sphere Project, 2004).

From the discussion above it is clear that the need for a coordinated approach to disaster relief was gradually being addressed. More recent, the relief coordination of the Indian Ocean tsunami disaster on 26 December 2004, showed that significant strides has been made in international aid coordination. The development of modern media technology and the ability to broadcast live images from disaster stricken area gradually brought the need for global intervention in major disasters to the general public in many developed countries.

\section{The international media}

In the 1970s and 1980s several major disasters, such as the 1973/4 Sahel drought and relating famine, the 1974 Bangladesh floods, the Guatemalan earthquake of 1976, the Andhra, Pradesh cyclone in India in 1977, the Bhopal, India chemical release in 1984, the repeat of the 1973 Ethiopian famine in 1984, the great 1985 Mexico City earthquake, Chernobyl in 1986 and the Exxon Valdes oil spill in Prince William Sound, attracted global media attention. Taken together, they strained international capacity to provide effective and timely emergency relief services. In addition to this several of these events had a high political profile, particularly among major industrialised countries.

Media coverage of these disasters transmitted vivid images of suffering and devastation into the homes of the MDCs, sparking a global outcry and outreach to these communities. Many relief organisations were quick to realise the usefulness of international television and soon used it to their benefit. An example of how the media influences relief is surely the coverage of the 2000 Mozambique floods in Southern Africa. Most relief organisations were mobilised long before the Mozambique government made the official call for international assistance (Klopper, 2000).

Continuing today, the role of the international media cannot be underestimated. Global media networks possess, in most cases, vastly more resources and field personnel than even some of the most established relief organisations. The international media has become an intricate (albeit transient) part of the international relief system in terms of communication, aid mobilisation and influencing public opinions on a disastrous event. It is with no doubt that the international news media can play a crucial role in disaster risk reduction. The sensational focus of the news media on the death toll and extent of low frequency - high impact events (such as 9/11, Hurricane Katrina and the Indian Ocean tsunami) remains an obstacle. Beside the role of the media the most important component within the relief system is the recipients of the aid and the workers within these affected communities. 


\section{Local communities and projects}

The final tier identified by Cuny (1983) is that of the community and project level. At this level the funds and resources mobilised and allocated through the preceding tiers, are dispersed and the needs of the affected communities are addressed. These projects can take on a variety of different forms. Cuny (1983) criticised the international relief mechanism for not taking the communities' coping capacity into account when developing relief programmes. He clearly stipulated the need for developmental interventions to improve development as well as an enhanced state of affairs than that prior to the disaster. The need for vulnerability reduction planning within a development focus comes to the fore. It should, however, be noted that some significant changes occurred in the international relief system. These changes will be discussed briefly.

\section{Changes in the international relief system}

The Kurdish refugee crisis of April 1991 involved the movement of 1.9 million people fleeing oppression by Iraqi Government forces (ODI, 1993). Seventy percent of the refugees were able to cross into Iran where they were comparatively well cared for by the local authorities and the Iranian Red Crescent. Most of the refugees who moved towards Turkey were prevented from crossing the border by the Turkish authorities and were stranded on exposed, high altitude sites on the Iraqi side of the border (ODI, 1993).

The international community responded with a number of actions. The most significant being the passage of Security Council Resolution 688 on 5 April 1991 (UN, 1991) which insisted "that Iraq allow immediate access by international humanitarian organisations to all those in need of assistance in all parts of Iraq". The United States of America, Britain, France and the Netherlands aimed to establish safe havens within northern Iraq to enable Kurds to move down to more sheltered sites within Iraq where they were protected from attack by Iraqi government forces. A further action was the mounting of a massive relief operation in which military forces (principally transport aircraft and helicopters, but also medical professionals and management) played a crucial role in delivering assistance, together with the UN agencies and international NGOs.

The Kurdish operation established the important precedent that, under certain circumstances, the international community is prepared to use force in support of humanitarian relief operations (ODI, 1993). In addition, the response sharply exposed the weaknesses in coordination mechanisms and in the ability of the system to rapidly deliver assistance in areas where agencies of the host government could not be used and where few international NGOs operated prior to the intervention. This operation created precedents because of the context in which it occurred. The performance of UN agencies involved in the provision and coordination of relief during the Kurdish 
operation was criticised by some western governments, during and after the operation. Such criticisms focused upon the slow response of the principal UN agencies to the opportunities created by the passage of Resolution $688^{2}$, the perennial lack of inter-agency coordination and the lack of leadership provided by the UN system to the numerous other agencies (donor, NGO and intergovernmental) involved in the response.

The collapse of the former Soviet Union and the ending of the Cold War witnessed a convergence of USA and Russian interests on many foreign policy issues, simultaneously reducing the need for Russia to use its veto powers in the Security Council and increasing the costs to it of doing so. This has radically enhanced the capacity of the Security Council to address and act upon international security and humanitarian issues.

Whilst Resolution 688 established an important precedent, subsequent events indicate a continuing struggle between those favouring a more interventionist approach and those arguing against it on the grounds of national sovereignty (ODI, 1993). Within the General Assembly the former group has faced considerable opposition. Thus, initial drafts of General Assembly Resolution 46/182 of 19 December 1992 (UN, 1992) aimed at improving the UN's coordination of the international relief system sought to sustain the impetus for the more interventionist approach resulting from Resolution 688.

The final text of General Assembly Resolution 46/182 aimed at improving the UN's coordination of relief states:

The sovereignty, territorial integrity and national unity of states must be fully respected in accordance with the Charter of the United Nations. In this context, humanitarian assistance should be provided with the consent of the affected country and in principle on the basis of an appeal by the affected country.

The text leaves some room for humanitarian intervention. Its use of the phrases "should be" and "in principle" allows for instances when assistance can be provided without an appeal by the affected state or even without its consent.

The changes may be seen as the adaptation of international relief system to the ending of the Cold War and the collapse of the Soviet Union. These events have simultaneously enhanced the capacity of the Security Council to undertake armed intervention in support of humanitarian objectives, removed the capacity for central control over a host of newly unleashed ethnic tensions, and opened up new roles for armed forces built up during the Cold War period. Within this

2 UN Resolution 688 (1991) insists that, although the sovereignty of Iraq is acknowledged, Iraq "allow immediate access by international humanitarian organisations to all those in need of assistance in all parts of Iraq and to make available all necessary facilities for their operations." 
new context the power of the richer western governments to influence the pace and direction of change within the international relief system, were significantly enlarged, by virtue of their central role in resourcing the international relief system and, in the case of France, UK and USA, through their membership of the Security Council (ODI, 1993). The enhanced role of the Security Council increases the likelihood that relief assistance will be provided to civilian populations in conflict zones. However, an apparent lesson from the cases of Somalia and Bosnia is that armed interventions in support of humanitarian relief objectives are likely to be crucially dependent upon the prevailing attitudes and concerns of the richer western governments, especially the USA.

On the African continent a more direct involvement by African governments to African crises has also become evident since 1994 (Neethling, 2004). The democratic elections in South Africa, the strengthening of Pan African sentiment, the establishment of the African Union and the new developmental focus on Africa through NEPAD, all contributed to peacekeeping and humanitarian interventions by African countries. As is the case with the UN Security Council, the African Union has not significantly shown vigour in intervening in countries in conflict (e.g. Rwanda, Sudan, DRC and also Zimbabwe to an extent). It should, however, be highlighted that peacekeeping and peace making on the African continent should not be confused with relief. To this end, the African relief mechanism is severely limited in its capacity, and many African nations remain the receivers of international relief.

In perusal of the "new" international relief system it becomes clear that the provision of assistance is not a unilateral mechanism anymore. Moreover countries dependent on relief are aiming to link the provision of relief with developmental initiatives (SCUK/C, 2004, Ellis \& Barakat, 1996).

\section{Influence of the development agenda}

Already in 1976, Ritchie (1976) noted the importance of development in preventing disasters. The seminal publication of Cuny (1983) as well as the work of Randolph C. Kent (Anatomy of Disaster Relief: The International Network of Action published in 1987), explored the importance of development and vulnerability in creating or exacerbating disasters (Lavell, 1999). The theme of disasters, environment and sustainability, appeared in a number of works edited by Kreimer (1989), Kreimer and Zador (1989) as well as Kreimer and Munasinghe (1991) towards the end of the 1990s. Cuny paid particular attention to the role of development in emergency assistance and proclaimed that emergency issues should be addressed in the context of much larger development policies. It is widely accepted that Cuny was the first to address the disasterdevelopment interaction mostly due to his direct involvement in the international dimension of disaster/emergency management (Jeggle, 
2005; Lavell, 1999).

Kent researched the complexity of the causes of disasters being rooted in conditions of vulnerability. They (Cuny and Kent) questioned the validity of cyclical disaster occurrences and emphasised the importance of a holistic approach towards disasters, although from two different perspectives. Mary Anderson (1985) also added considerable thought to this debate during the latter part of the 1980s. Anderson and Woodrow (1989) advanced the concept of incorporating vulnerability reduction in development activities (Jeggle, 2003).

The above-mentioned authors came from a wide array of different disciplines with varied direct involvement in situations of disasters, yet they all realised that the occurrence of disasters (be it natural or human induced) can, and should, be addressed through a change of focus. Such a change of focus was to address the root causes of disaster mostly through developmental interventions. The emphasis on the types of developmental interventions towards disaster reduction varied from author to author, and ranged from the adaptation of public policy to direct community-based development projects for vulnerability reduction. Notwithstanding the above, the late 1980s heralded a new era in the management of disasters and the provision of disaster relief.

\section{New focus for disaster relief}

Hammock and Nastsios (in Cuny, 1999) state that one of the traditional weaknesses of humanitarian agencies has been their inability to be reflective and undertake objective analysis of their relief response on a more strategic level (i.e. also considering long term developmental actions linked to relief). It was widely felt by the scientific community (Gunn, 1992; Quarantelli, 1998) and professional groups, that there had to be a more effective way of responding to disasters than only providing relief materials to the survivors (Jeggle in Rosenthal, Comfort \& Boin, 2001; Comfort et al., 1999). The concept of disaster management progressively found its way into the vocabulary of international relief organisations and policy makers.

The disaster events of the 1970s to late 1980s mentioned previously, intensified the drive towards the development of a better global system in terms of disaster preparedness (Taylor \& Cuny, 1979; Burton, 1993). A realisation grew that the international relief mechanism was not geared for such events. This motivated the international assistance community, typically accompanied by NGOs involved in emergency assistance responsibilities, to give greater public visibility and policy commitment to preparedness in disaster management (Jeggle in Rosenthal, Comfort \& Boin, 2001). A more comprehensive sense of disaster preparedness and management that encompassed functions of preparedness, prevention, mitigation, reconstruction and rehabilitation began to be more widely recognised as a much needed 
alternative to disaster relief.

\section{Disaster preparedness and management}

Blaikie et al (1994) and Wisner et al (2004) indicate that in the early part of the 1970s, the term "disaster prevention" was used freely. UNDRO later questioned the use of "prevention" because it argued that a disaster cannot be prevented, only mitigated (UNDRO, 1991). The terms prevention, preparedness and mitigation were also frequently confused. Disaster mitigation (actions taken to reduce damage or loss) signified a new paradigm towards disaster reduction and so too expanded on the ideas of disaster preparedness and management. This is quite evident of the theoretical writings of scholars in this era.

Technological advancement in the twentieth century made it possible to apply and mobilise resources in order to reduce (or mitigate) the impacts of natural hazards. One of the first steps in turning the focus of emergency assistance was applied to the field of pre-disaster emergency procurement and shipment procedure for food. This also included the establishment of forward warehouses for emergency food stock around the world. Although the ensuring of food stock was given priority, other interests in broader preparedness planning gradually won commitment towards the improvement of "readiness of response" (Jeggle in Rosenthal, Comfort \& Boin, 2001). Through compiling contingency plans, setting up disaster relief teams, and stockpiling emergency relief material, NGOs and relief organisations progressively developed the concept of preparedness into a more focused facet of emergency relief assistance (Black, 1992).

Progress in technology also brought with it new possibilities in terms of early warning systems for specific hazards (Lavell, 1999). This is clearly illustrated by the USAID-sponsored Famine Early Warning System (FEWS), and the UN Food and Agricultural Organisation's Global Information and Early Warning System (GIEWS). Lavell (1999) indicates that the progress in technology also brought with it new risks relating to the uncertain application of these technologies.

The end of the 1980s saw a keen interest within the international community towards the systematic development of methodologies which could be applied to ensure even better pre-disaster preparedness (Rouhban in Ingleton, 1999). Gradually the common use of the concept "disaster management" emerged. The central paradigm of the integrated approach towards disaster management can be viewed in a common timeframe cutting across natural hazards as a sequence of phases each being amenable to a specific type of intervention (e.g. planning phase, preparedness phase, prevention phase, mitigation phase, warning phase, disaster impact phase, rescue phase, relief phase, rehabilitation phase, and reconstruction and recovery phase) (Lechat, 1990; UNDP, 1992). Disaster management aimed towards the integration of pre- and post-disaster activities in 
order to safeguard lives and property against possible disasters.

Jeggle (in Rosenthal, Comfort \& Boin, 2001) compares the earlier concepts of emergency assistance and disaster management. He points out that there are distinctive managerial and functional implications for the organisation of risk and disaster management for the future. These are summarised in Table 1 below.

\section{Table 1: Emergency assistance vs. Hazard, risk and disaster management}

\begin{tabular}{|c|c|}
\hline Emergency assistance & Hazard, risk and disaster management \\
\hline Primary focus on HAZARDS. & Major focus on VULN ERABILITY. \\
\hline Single, event-bas ed scenarios. & Dynamic, multiple risk issues. \\
\hline $\begin{array}{l}\text { Basic responsibility to respond to an event. } \\
\text { Often fixed, location-specific conditions. } \\
\text { Responsibility in single authority or agency. }\end{array}$ & $\begin{array}{l}\text { Fundamental need to assess, update. } \\
\text { Extended, shared or regional locales. } \\
\text { Multiple interes ts, ac tors, respons ibilities. }\end{array}$ \\
\hline Command and control, directed operations. & Situation-specific functions, free association. \\
\hline $\begin{array}{l}\text { Established hierarchical relationships. } \\
\text { Urgent, immediate-to-short time frames in } \\
\text { outlook, planning, attention, returns. }\end{array}$ & $\begin{array}{l}\text { Shifting, fluid and tangential relationships. } \\
\text { Comparative, moderate-to-long time frames in } \\
\text { outlook, planning, return values. }\end{array}$ \\
\hline $\begin{array}{l}\text { Rapidly changing, dynamic information usage. } \\
\text { Often conflicting or "sensitive". }\end{array}$ & $\begin{array}{l}\text { Accumulated, historical, layered-updated } \\
\text { comparative, information. Open or public. }\end{array}$ \\
\hline Primary, "authorised" or singular sources. & Multiple and diverse or changing sources. \\
\hline Need for definitive "facts". & Differing perspectives, points of view. \\
\hline $\begin{array}{c}\text { Operational, or public information-based use of } \\
\text { communications. }\end{array}$ & $\begin{array}{l}\text { Multiple-use, shared exchange, inter- sectoral } \\
\text { information, matrixes, nodal, lateral flows in } \\
\text { communication. }\end{array}$ \\
\hline
\end{tabular}

(Source: Jeggle in Rosenthal, Comfort and Boin, 2001)

From the above table it is therefore clear that changing organisational and institutional roles in disaster management marked a 
fundamental shift towards vulnerability and risk management for the future. Jeggle (2003), however, cautions that one should not assume that disaster risk reduction developed or evolved from the earlier understanding of disaster management. The focus on disaster risk reduction rather developed due to the work of a number of different professional disciplines, all with one aim in mind - to reduce the risk of disasters occurring or affecting people.

The evolution of disaster management did, however, ensure a realisation that hazard and risk relate to significantly larger professional constituencies. The discriminating focus of the international scientific community, different professional constituencies, and national administrators on disasters brought with it the recognition that intervention is needed on a professional and administrative scale.

\section{International mechanisms that shaped disaster risk reduction}

Although the United Nations' various agencies have to a greater and lesser degree been involved in response to disasters, which normally translated into humanitarian crisis, no one agency was dedicated to purely focussing on issues relating to disasters. The inadequacies of the international relief and humanitarian system to address continuous losses due to natural disasters brought with it a realisation that alternative interventions are needed. An international decade on natural disasters was first proposed at the Eighth International Congress of Earthquake Engineering (Lechat, 1990). The international scientific community met this initiative favourably.

In December 1987, the United Nations General Assembly adopted Resolution 42/169 which proclaimed the years 1990-1999 as the International Decade for Natural Disaster Reduction, or IDNDR (WMO, 1997; Smith, 2002; UNISDR, 2002; UN, 1987; Lechat, 1990). During this decade a concerted international effort was attempted to reduce the loss of life, property, livelihoods, and social and economic disruption caused by the violent impact of nature on vulnerable conditions. The aim of this decade was to ensure a shift in the reactive approach towards natural disasters to that of pro-active planning and prevention (Housner, 1989; Lechat, 1990; Smith, 2002).

Another significant event which shaped the disaster risk reduction agenda in the 1990s was the World Conference on Natural Disaster Reduction held in Yokohama, Japan from 23-27 May 1994 and the subsequent adoption of the Yokohama Strategy and Plan of Action for a Safer World.

The Yokohama Strategy and Plan of Action for a Safer World (1994) stressed that each country has the sovereign responsibility to protect its citizens from natural disasters and that priority must be given to developing countries, in particular the least developed, land-locked 
countries and the small island developing states. It further emphasised the importance of:

developing and strengthening national capacities and capabilities and, where appropriate, national legislation for natural and other disaster prevention, mitigation and preparedness, including the mobilisation of non-governmental organisation and participation of local communities (Yokohama 1994).

Lastly, the strategy pointed to the importance of promoting and strengthening sub-regional, regional and international cooperation in prevention, reduction and mitigation of natural and other disasters. The IDNDR cultivated fertile soil for the announcement of its successor, The International Strategy for Disaster Reduction (ISDR) in 2000 .

As the successor to the IDNDR, the International Strategy for Disaster Reduction (ISDR) proceeded with the emphasis of protection against hazards, reducing vulnerability and building resilient communities (UNISDR, 2002). The most significant progress that the ISDR aims to make, vis-à-vis the ideals of the IDNDR and the Yokohama Strategy and Plan of Action for a Safer World, is the cultivation of a multidisciplinary approach to disaster reduction within the broader context of sustainable development (UNISDR, 2004). The ISDR takes a global approach to disaster reduction inculcating a culture of risk avoidance behaviour through the fostering of partnerships at community level.

One of the major emphases of the ISDR is ensuring political commitment to the development and implementation of disaster reduction policies and actions by all governments, but in particular those most exposed to the possible impact of hazards. Stimulating interdisciplinary and intersectoral collaboration and the expanding of existing networks is one of the key focus areas of the ISDR. Learning from the IDNDR, the ISDR calls attention to the importance of research and the improvement of scientific knowledge of disaster reduction.

In December 2003 (UN, 2003), the UN General Assembly adopted resolution 58/214, in which it decided to convene a second World Conference on Disaster Reduction. As mentioned previously, the first World Conference on Disaster Reduction took place in Yokohama, Japan in May 1994 and set a plan of action called the Yokohama strategy. The WCDR adopted the Hyogo Declaration, and the Hyogo Framework for Action 2005-2015: Building the Resilience of Nations and Communities to Disasters, which aims to define a new plan of action for the years 2005-2015 to facilitate the implementation of the Millennium Development Goals ${ }^{3}$. Some scholars, however, are of the

3 The Millennium Development Goals (MDGs) form a blueprint agreed to by all the countries of the world and the world's leading development institutions to aim and achieve eight development goals by 2015. (See http://www.un.org/ millenniumgoals/). 
opinion that the Hyogo Framework for Action (UN, 2005) failed dismally in linking the Kobe outcomes with the goals and targets set out in the Millennium Development Goals (Walker \& Wisner, 2005:1).

Despite the good efforts by government, non-governmental actors, civil society and various research and academic disciplines, the reduction of disaster risk in communities most at risk remains a challenging task.

\section{Conclusion}

This article aimed to explain the complex historical development of the focus on disasters and disaster relief to disaster risk reduction. It was found that the modern focus on disaster risk reduction cannot be ascribed to a logical flow of events linked to a specific timeframe, or can it be ascribed to a natural evolution of a discipline. Rather, it was shown that various international disasters, professional constituencies and international organisations contributed to its development. Although some aspect such as the disaster relief agenda and disaster response played a major role in the development of the term, it was the relative lack of prevention measures to disaster events which cemented this international focus. The combined efforts of the international community, lead by the United Nations, brought a commitment to disaster risk reduction on a political and policy level. Although massive strides have been made in the past number of decades towards more focused and robust disaster mitigation and reduction measures, their alignment with development goals and gains is still lacking.

\section{References}

ALEXANDER, D. 1993. Natural Disasters. New York: Chapman \& Hall.

ANDERSON, M. 1985. A reconceptualization of the linkages between disasters and development. Disasters. Harvard Supplement.

ANDERSON, M.B. \& WOODROW, P.J. 1989. Rising from the ashes: Development strategies in times of disaster. Boulder: Westview Press.

BLACK, M. 1992. A cause for our time: OXFAM the first 50 years. Oxford: Oxfam.

BLAIKIE, P. CANNON, T. DAVIS, I, \& WISNER, B. 1994. At risk: Natural hazards, people's vulnerability, and disasters. New York: Routledge.

BURTON, I., KATES, R.W \& WHITE, G.F. 1993. The environment as hazard. 2nd Edition. New York: Guilford.

BORTON, J. 1993. Recent Trends in the International Relief System. Disasters. 17. 3. 
Canadian International Development Agency (CIDA). 2008. CIDA in Brief. [Web: http://www.acdi-cida.gc.ca/CIDAWEB/ acdicida.nsf/En/JUD-829101441-JQC]. [Date of access: 17 August 2008].

CHRISTIAN RELIEF AND DEVELOPMENT ASSOCIATION (CRDA). 2004. About CRDA. [Web: http://www.crdaethiopia.org]. [Date of access: 10 September 2004].

COMFORT, L., WISNER, B., CUTER, S., PULWARTY, R., HEWITT, K., OLIVER-SMITH, A., WIENER, J., FORDHAM, M., PEACOCK, W. \& KRIMGOLD, F. 1999. reframing disaster policy: The global evolution of vulnerable communities. [Web: http:// jishin.ucsur.pitt.edu/publications/Reframing.htm]. [Date of access: 30 August 2004].

CUNY, F. C. 1983. Disasters and Development. Oxford: Oxford University Press.

CUNY, F. C. (with HILL, R.B.). 1999. Famine, conflict and response: A basic guide. Connecticut: Kumarian Press.

DEPARTMENT FOR INTERNATIONAL DEVELOPMENT (DFID). 2004. DFID historical background. [Web: http://www.dfid.gov.uk/ aboutdfid/history.asp]. [Date of access: 15 November 2004].

Deutsche Gesellschaft für Technische Zusammenarbeit (GTZ) GmbH. 2008. Corporate Profile. [Web: http://www.gtz.de/en/ unternehmen/1698.htm]. [Date of access: 17 August 2008].

ELLIS, S. \& BARAKAT, S. 1996. From Relief to Development: The Longterm Effects of 'Temporary' Accommodation on Refugees and Displaced Persons in the Republic of Croatia. Disasters. 20. 2.

GREEN, S. 1977. International disaster relief: Towards a responsive system. New York: McGraw-Hill.

GUNN, S.W.A. 1992. The Scientific Basis of Disaster Management. Disaster Prevention and Management. 1. 3. 16-21.

HOUSNER, G.W. 1989. An international decade for natural disaster reduction, 1990-2000. Natural Hazards. 2. 45-75.

INGLETON, J. (Ed.) 1999. Natural Disaster Management. UK: TudorRose.

INTERNATIONAL STRATEGY FOR DISASTER REDUCTION (ISDR). 2004b. Living with risk: A global review of disaster reduction initiatives. Geneva: ISDR Secretariat.

JEGGLE, T. (tjeggle@hotmail.com). Senior Disaster Risk Advisor: International Strategy For Disaster Reduction - UN. 2003. Terminology. [E-mail to:] Ritchie, G.N. (gnritchie@supanet.com). 9 September.

JEGGLE, T. (tjeggle@hotmail.com). 2005. Senior Disaster Risk Advisor: International Strategy For Disaster Reduction - UN. The 
international relief mechanism. [E-mail to:] Van Niekerk, D. (pwsdvn@puk.ac.za).15 April.

KENT, R.C. 1987. Anatomy of disaster relief: The international network of action. London: Pinter Publishers.

KLOPPER, J. (Lt. Col.). 2000. Commanding and Coordinating Officer: International Military Rescue and Relief Effort in Mozambique. Interview with author. 29 February.

KREIMER, A. 1989. Reconstruction after Earthquakes: Sustainability and Development. Washington D.C.: The World Bank.

KREIMER, A. \& MUNASINGHE, M. (Eds). 1991. Managing Natural Disasters and the Environment. Washington D.C.: The World Bank.

KREIMER, A. \& ZADOR, M. (Eds). 1989. Colloquium on Disasters, Sustainability and Development: A Look at the 90s. Environmental Document No. 23. Washington D.C.: The World Bank.

LAVELL, A. 1999. The Impact of Disasters on Development Gains: Clarity or Controversy. IDNDR Programme Forum., 5-9 July. Geneva, Switzerland.

LECHAT, M.F. 1990. The International Decade for Natural Disaster Reduction: Background and Objectives. Disasters. 14. 1. 1-6.

MOORE, H. 1956. Towards a theory of disaster. American Sociological Review. 21. pp734-737.

NEETHLING T. 2004. International peacekeeping trends: the significance of African contributions to African peacekeeping requirements. Politikon: South African Journal of Political Studies. May. 31. 1.

OFFICE FOR THE COORDINATION OF HUMANITARIAN AFFAIRS (OCHA). 2008. A Brief History of OCHA. [Web: http:// ochaonline.un.org/AboutOCHA/HistoryofOCHA/tabid/4393/ language/en-US/Default.aspx]. [Date of access: 13 November 2008].

OVERSEAS DEVELOPMENT INSTITUTE (ODI). 1993. Recent changes in the international relief system. London: ODI.

PELling, M. 2003. Natural Disasters and Development in a Globalizing World. London: Routledge.

QUARANTELLI, E.L. (Ed). 1998. What is a disaster?: Perspectives on the question. London: Routledge.

RITCHIE, G.N. 1976. Monograph: UN Agencies, the Commonwealth and NGOs. Department of Administration Studies. Manchester: University of Manchester.

RITCHIE, G.N. 2004. Founder and previous director of the Cranfield 
Disaster Management Centre. Communication with author. 28 December.

ROSENTHAL, U. COMFORT L. \& BOIN, A. 2001. Managing Crisis: A Global Perspective. USA: C.C. Thomas Publishers.

SAVE THE CHILDREN UK/CANADA (SCUK/C). 2004. Employment Generation Schemes in Ethiopia: What lessons can be drawn from recent experience?. Institutional Support Project for Disaster Prevention and Preparedness Commission. Addis Ababa: Save the Children UK/Canada.

SPHERE PROJECT. 2004. Humanitarian Charter and Minimum Standards in Disaster Response. [Web: http:// www.sphereproject.org/content/view/27/84/lang,english/]. [Date of access: 10 November 2008].

SMITH, K. 2002. Environmental Hazards: Assessing risk and reducing disaster. 3rd Edition. London: Routledge.

TAYLOR, A. J. \& CUNY, F.C. 1979. The Evaluation of Humanitarian Assistance. Disasters. 3. 1.

TODARO, M.P. 1994. Economic Development. 5th Edition. New York: Longman.

UNITED NATIONS (UN). 1971. General Assembly Resolution 2816. Assistance in case of natural disaster and other disaster situations. 14 December. Geneva: UN.

UNITED NATIONS (UN). 1987. General Assembly Resolution 42/169. The International Decade for Natural Disaster Reduction. 3 February. Geneva: UN.

UNITED NATIONS (UN). 1992. General Assembly Resolution 46/182. Strengthening of the coordination of humanitarian emergency assistance of the United Nations. 19 December. Geneva: UN.

UNITED NATIONS (UN). 2003. General Assembly Resolution 58/214. World Conference on Disaster Reduction. 23 December. Geneva: UN.

UNITED NATIONS (UN). 2005. Report on the World Conference on Disaster Reduction. Kobe, Hyogo, Japan, 18-22 January 2005. A/CONF.206/6. 16 March 2005.

UNITED NATIONS CHRONICLE. 1985. When disaster strikes...the United Nations response to natural disasters. September. Geneva: UN.

UNITED NATIONS DEVELOPMENT PROGRAMME (UNDP). 2004. Reducing disaster risk: A challenge for development. Bureau for Crisis Prevention and Recovery. New York: John S. Swift Co.

UNITED NATIONS DEVELOPMENT PROGRAMME (UNDP). 1992. An Overview of Disaster Management. Geneva: UNDP-DMTP. 
UNITED NATIONS DISASTER RELIEF OFFICE (UNDRO). 1991. Mitigating natural disasters: Phenomena, effects and options - A manual for policy makers and planners. Geneva: UNDRO.

UNITED NATIONS INTER-AGENCY SECRETARIAT OF THE INTERNATIONAL STRATEGY FOR DISASTER REDUCTION (UNISDR). 2002. ISDR background paper for WSSD. Geneva: UN.

UNITED NATIONS INTER-AGENCY SECRETARIAT OF THE INTERNATIONAL STRATEGY FOR DISASTER REDUCTION (UNISDR). 2003. Living with Risk: Turning the tide on disasters towards sustainable development. Preliminary Version. Geneva: ISDR.

UNITED NATIONS INTER-AGENCY SECRETARIAT OF THE INTERNATIONAL STRATEGY FOR DISASTER REDUCTION (UNISDR). 2004. The mission and objectives of the ISDR. [Web: http://www.unisdr.org/eng/about_isdr/isdr-missionobjectives-eng.htm]. [Date of access: 22 July 2004].

UNITED STATES AGENCY FOR INTERNATIONAL DEVELOPMENT (USAID). 2004. About USAID. [Web: http://www.usaid.gov/ about_usaid/usaidhist.html]. [Date of access: 11 September 2004].

WALKER, P. \& WISNER, B. 2005. Twelve big questions for Kobe and beyond. (unpublished).

WATKINS, T. 2003. The great leap forward period in China 1958-1960. [Web: http://www2.sjsu.edu/faculty/watkins/greatleap.htm]. [Date of access: 15 November 2004].

WILLIAMS, K. 2005. Online comment: Dialogue on millennium development goals and disaster risk reduction. 28 July. [Web: http://www.unisdr.org/mdgs-drr-dialogue/dialogue.htm]. [Date of access: 10 November 2008],

WISNER, B., BLAIKIE, P., CANNON, T. \& DAVIS, I. 2004. At Risk: Natural hazards, people's vulnerability and disasters. $2^{\text {nd }}$ ed. London: Routledge.

WORLD BANK. 2008. World Development Indicators Database. [Web: http://ddp-ext.worldbank.org/ext/DDPQQ/ member.do?method=getMembers\&userid=1\&queryId=135]. [Date of access: 11 November 2008].

WORLD METEOROLOGICAL ORGANIZATION (WMO). 1997. Comprehensive Risk Assessment for Natural Hazards. WMO/ TD No. 955. Geneva.

YOKOHAMA STRATEGY AND PLAN OF ACTION FOR A SAFER WORLD. 1994. Guidelines for Natural Disaster Prevention, Preparedness and Mitigation. World Conference on Natural Disaster Reduction. Yokohama, Japan, 23-27 May. 
